\title{
RINHAS DE GALOS NO LITORAL NORTE PARAIBANO: PERFORMANCES EM UM ESPORTE INTERÉTNICO
}

\author{
Rafael Leal Matos ${ }^{1}$
}

\section{Introdução}

Este artigo resulta de uma dissertação de mestrado $^{2}$, na qual busquei compreender o universo da briga de galos do litoral norte paraibano, ou seja, a relação entre humanos e animais, e as dinâmicas de interação entre indígenas e não indígenas locais - tendo em vista que esta é uma região caracterizada pelo contato interétnico entre os Potiguara ${ }^{3}$ e a população de não indígena.

A briga entre galos há muito tem sido um fenômeno que desperta o interesse humano. "Estudos apontam o Sul e Sudoeste da Ásia como prováveis locais de existência e domesticação, o que pode ter ocorrido há mais de 5.000 anos" (Corrêa, 2014: 200). Ainda segundo o autor citado, antes de figurarem enquanto elemento do nosso cardápio alimentar, estes animais foram domesticados para rinha ${ }^{4}$.

Meu interesse por briga de galos surgiu em campo, em meados de 2013. Ao realizar uma pesquisa para concluir a graduação - sobre o consumo de bebidas alcoólicas numa determina aldeia Potiguara (Matos, 2013) - soube que um dos meus interlocutores costumava frequentar rinhas. Convidado por ele, assisti minha primeira briga de galos. Vi homens reunidos, galos brigando, gritos, apostas, sangue, bebidas alcoólicas, risadas, hostilidades, brincadeiras... Saí pasmo do local, pois percebi que não havia compreendido quase nada do que se passara diante de mim! Passei a me questionar de diversos modos. Quais os significados dessa prática num contexto de relações e interações interétnicas ${ }^{5}$ ? Por que homens (indígenas e não indígenas) se

\footnotetext{
${ }^{1}$ Universidade Federal do Tocantins, Brasil.

2 Defendida em fevereiro de 2016 no Programa de Pós-Graduação em Antropologia Social (PPGAS) da Universidade Federal do Rio Grande do Norte (UFRN), sob a orientação de Rita de Cássia Maria Neves.

${ }^{3}$ Etnia que faz parte de uma grade unidade, estabelecida na etnologia brasileira e pelo movimento indígena, conhecida como "Índios do Nordeste". Segundo Oliveira (1998) os indígenas dessa grande unidade são vistos e se compreendem como "Índios Misturados".

${ }^{4}$ De acordo com o dicionário online Michaelis, esta é uma palavra derivada do termo castelhano "riña", que significa briga. No Brasil, este termo serve para designar brigas entre animais promovidas por humanos, o que faz com que tal termo sirva também para se referir ao local físico onde as brigas são realizadas.

5 Nas pesquisas que tratam sobre o contato interétnico é comum a utilização da expressão "relação interétnica". Optei por utilizar também a expressão "interação interétnica" para dar ênfase aos encontros face a face. Isso porque algumas situações de contato são melhores expressas pelo conceito "interação
} 
reuniam para colocar estes animais em combate, torcer e apostar mesmo sabendo que é uma prática ilegal? Como se dá a relação entre homens e galos? As fronteiras interétnicas são borradas e/ou acentuadas nestes espaços? Quais as práticas de bastidores? Como se faz um galo de briga?

O estopim para que eu decidisse pesquisar a briga de galos no mestrado foi à leitura do texto de Clifford Geertz (1978) "Um Jogo Absorvente: notas sobre a briga de galos balinesa". Apesar de saber da existência desse escrito, presenciei a briga citada acima sem ainda tê-lo lido. Através desse escrito, ficou claro ser viável uma pesquisa sobre briga de galos, pois na cabeça de um graduando não era fácil decidir pesquisar uma atividade controversa e ilegal.

Já no mestrado, estive em campo por quarenta e um dias, distribuídos em três etapas. A primeira de apenas três dias (entre 17 e 19 de outubro de 2014), quando reestabeleci alguns contatos e, mesmo sem ter frequentado nenhuma rinha, conversei com alguns galistas $^{6}$ sobre o meu interesse de pesquisa. Na segunda etapa permaneci em campo por vinte e seis dias (de 15 de janeiro a 09 de fevereiro de 2015). Nesse período conheci novas pessoas, frequentei brigas e criações. Por fim, voltei em um terceiro momento, que compreendeu em uma estadia de doze dias (entre 11 e 22 de março de 2015). Ao todo conheci quatro criações e frequentei nove dias de briga de galos, em cinco rinhas distintas, sempre aos fins de semana: seis delas aos sábados e outras três aos domingos.

Antes de dar seguimento, gostaria de dizer que a grande maioria das brigas de galos, que frequentei, podem ser tidas como verdadeiras "peladas" 7 , se tomarmos de empréstimo uma imagem do universo futebolístico. Participei de rinhas que somavam entre quinze e cem indivíduos. Alguns desses encontros se configuravam no formato de um torneio, com cobrança de entrada e premiação ${ }^{8}$ para o galista vencedor; outros eram encontros mais informais, sem cobrança de entrada, sem premiações, apenas com

social" (Goffman, 1985) do que pelo de "relação social". Sendo assim, quando eu utilizar o termo "interação interétnica" estarei me referindo ao contato face a face entre indígenas e não indígenas. Já quando utilizar o termo "relações interétnicas" estarei falando sobre outras facetas desse contato que, por ventura, também incluem o encontro face a face.

${ }^{6}$ Termo usado pelos nativos para se referir aos criadores de galo de brigas.

${ }^{7}$ Expressão usada para designar jogos de futebol amadores. Quando um jogo profissional não se apresenta num nível satisfatório para os expectadores, geralmente, estes usam tal termo para denegrir o jogo em questão, como por exemplo: "esta partida tá parecendo uma pelada".

${ }^{8}$ Estas premiações variavam entre uma saca de milho ou de ração, até uma pequena premiação em dinheiro. 
apostas. Segundo meus interlocutores, existem rinhas mais "profissionalizadas", que são realizadas em cidades maiores (e nas suas regiões metropolitanas), como em João Pessoa - PB, Campina Grande - PB, Recife - PE e Natal - RN, para citar apenas rinhas de cidades já frequentadas por alguns sujeitos desta pesquisa.

\section{Métodos e Técnicas de Pesquisa}

Utilizei o método etnográfico e algumas de suas técnicas (observação participante, diário de campo, entrevistas formais e informais, olhar e ouvir atento e registro fotográfico). A partir da relação de confiança, que tal método exige e propicia, pude adentrar e ser aceito no circuito das rinhas, a tal ponto que consegui estabelecer uma relação "simétrica" com certos sujeitos da pesquisa, que deixaram de ser meros "informantes" e atuaram enquanto verdadeiros "interlocutores".

Segundo Cardoso de Oliveira (1995), a categoria de "informante" é transposta na medida em que a relação entre observador e observado torna-se dialógica, ou seja, é quando, no encontro etnográfico, se instaura uma relação cognitiva que vai além da mera coleta de informações, quando essa "relação caracteristicamente marcada como uma via de mão única, passa a ser de mão dupla” (Cardoso de Oliveira, 1995: 223).

Além dessa experiência dialógica, minha experiência pessoal, ou seja, a observação direta enquanto espectador das rinhas foi bastante decisiva. Tal observação foi realizada nos moldes de uma "observação participante" (Malinowski, 1908), ou melhor, de um "espectador participante", já que eu não me coloquei em campo como galista, mas sim como um espectador das rinhas. Isso possibilitou submergir no universo da briga de galos e compreender a lógica performática do grupo de galistas para entender e descrever como, na interação (Goffman, 1985), os atores sociais atribuem sentidos às suas ações e moldam-nas no tempo e no espaço.

\footnotetext{
9 Tais rinhas são de alto nível em vários sentidos. Segundo os sujeitos dessa pesquisa, elas têm uma infraestrutura muito melhor e mobilizam um número bem maior de pessoas e de dinheiro. Estas rinhas podem ser tidas enquanto verdadeiros centros, que servem de modelos para brigas de galos mais periféricas, como é o caso das que frequentei nessa pesquisa. Poucos são os galistas dessa pesquisa que já frequentaram ou que frequentam esses centros. Só os galistas mais renomados se atrevem a isso.
} 
Tendo em vista a ilegalidade das rinhas, a desconfiança perante minha pessoa era notável por parte de alguns sujeitos. Ao longo da estadia em campo, algumas estratégias e práticas foram imprescindíveis para definir a situação a meu favor. Alugar uma motocicleta ${ }^{10}$ para fazer o trabalho de campo foi fundamental. As pessoas citavam galistas e rinhas que eram, relativamente, distante do lugar onde eu me encontrava alojado, o que impossibilitava a viagem a pé.

Ao alugar a motocicleta, passei a ser visto de outra maneira pelos sujeitos da pesquisa, isso porque esse veículo de locomoção, o mais difundido na região, é certamente um símbolo de maioridade e de masculinidade ${ }^{11}$ (ideias bastante relevantes no universo da briga de galos). Além disso, ao estar motorizado, deixei de pedir caronas e passei a dar, o que me fez começar a ser chamado para as rinhas mais facilmente.

Outras questões merecem ser citadas por terem ajudado na minha inserção e aceitação em campo: o consumo de bebidas alcoólicas (mesmo que moderadamente) e o fato de ter apostado (mesmo que apenas duas vezes). O consumo de álcool e as apostas são práticas fundamentais do universo do galismo, sem elas não há briga de galos.

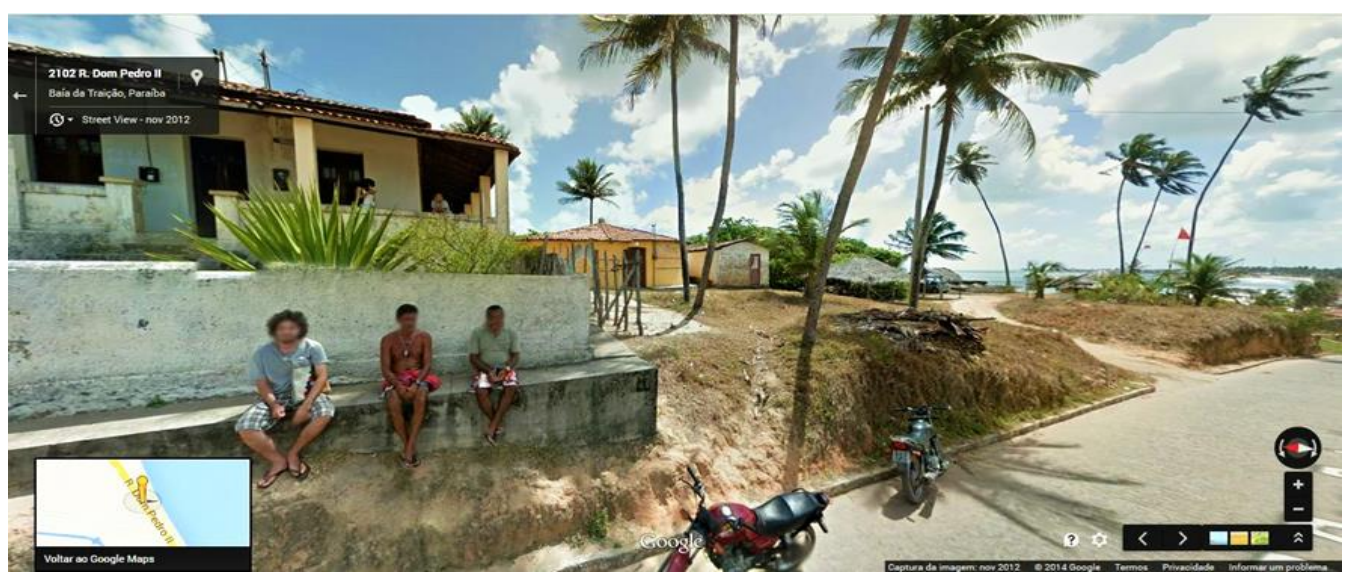

Imagem 1: As motos, os nativos e eu (à esquerda). Flagrados pelo Google Street View em frente ao Posto Indígena, ainda na minha pesquisa de graduação em novembro de 2013. Imagem retirada do Google Street View.

\footnotetext{
${ }^{10} \mathrm{~A}$ partir de alguns contatos, após procurar por mais de quatro dias, consegui alugar uma motocicleta com um indígena da região. Permaneci com este veículo por vinte, dos quarenta e um dias que estive em campo.

${ }^{11}$ Apesar de existir um número expressivo de mulheres, e até crianças pilotando motocicletas na região, a grande maioria das pessoas que possuem um veículo desses são homens adultos. É interessante destacar, para além disso, que estes veículos são pilotados, em quase cem por cento dos casos, sem o uso de capacetes, sem calçados adequados e sem retrovisores. As autoridades locais não punem que assim se porta. O estranho é andar de moto com estes itens de segurança. Alguém que faça isso ou está se dirigindo para as cidades maiores da região (onde há fiscalização) ou é reconhecido como um forasteiro. Por isso, seguindo o costume local, pilotei sem esses itens de segurança, para ser melhor reconhecido e aceito.
} 
A participação nesses eventos, a aposta e o consumo de álcool por parte do pesquisador, podem ser vistos por alguns mais moralistas como uma postura incorreta em campo. Porém, não haveria como pesquisar esse universo sem dele participar em certa medida. Eu não teria conseguido a confiança dos envolvidos nesta pesquisa sem beber em alguns momentos, e sem ter apostado quando fui desafiado. Isto porque essas duas práticas (beber e aceitar desafios), assim como pilotar motos, são encaradas como símbolos de masculinidade e maioridade. Não tenho dúvida que tais práticas me fizeram ser aceito mais facilmente.

\section{Briga de Galos: Bastidores e Rotinas}

Todos que participam da briga de galos consideram-na enquanto uma atividade esportiva, na qual o galo é considerado um atleta e o ser humano seu treinador. Apesar do questionamento dos que são contrários às rinhas (ambientalistas de maneira geral que discutem em blogs e sites sobre o tema), do ponto de vista antropológico, essa concepção nativa generalizada de esporte é bastante significativa. Ela apareceu para mim como uma metáfora que explica as práticas, ritos e sentidos que são engendrados nessa atividade. Segundo um dos meus interlocutores:

O povo diz que não, mas a briga de galo é um esporte. Quem fala isso é porque não conhece. $\mathrm{O}$ galo é um atleta muito bem cuidado. Não pode ter doença porque são atletas, né? Como todo atleta ele é bem tratado. Olha só aqui esse chiqueiro ${ }^{12}$, tá tudo limpo, né não?! Agora vá ver meu banheiro vê se num tá sujo! Primeiro eu cuido aqui dos galos, depois cuido de mim! A gente tem todo um cuidado na criação e no treinamento dessas aves. Tem remédio, pré-temporada e tudo mais. O galo só luta depois de bem tratado, de muito treino e descanso. Eles são atletas de verdade, verdadeiros gladiadores! Agora eu vou fazer o que se o instinto dele é brigar? Se ele não fizer isso nas rinhas vai fazer na natureza. (Zé Firmino ${ }^{13}$, galista que se percebe como descendente de índio e é reconhecido por seus pares como dono da melhor criação de um dos municípios dessa pesquisa. Entrevista concedida em 17 de março de 2015, em meio a sua criação).

\footnotetext{
12 Termo que designa o lugar onde os galos são criados, reproduzidos e treinados.

${ }^{13}$ Nome fictício.
} 
De fato, a briga de galos possui muitas semelhanças com o universo esportivo. Assim como numa série de esportes (MMA ${ }^{14}$ e o Futebol, por exemplo), essa atividade implica um setting, uma disputa, uma plateia e performers (que no caso são animais humanos e não humanos). Além disso, como percebemos no trecho da entrevista transcrito, existem concepções, termos e práticas utilizadas nas rinhas que são próprias do universo esportivo, como: treinamento, pré-temporada e uso de fármacos, por exemplo.

Os métodos e técnicas de criação e treinamento são fundamentais ${ }^{15}$. Sem eles não há galos de briga. Isso demonstra a importância dos bastidores dessa atividade. Esses animais são criados em quintais, nos chiqueiros. Os responsáveis pelo cotidiano dos mesmos é o tratador, que pode ser o próprio dono ou alguém contratado para isso. Os chiqueiros são também espaços de encontro entre galistas e admiradores que compartilham, entre si, métodos de criação e treinamento, formando uma verdadeira rede de relações, de parentes e amigos, que costumam frequentar as rinhas juntos, cooperar entre si através da partilha de um verdadeiro corpus de conhecimento e de materiais (remédios, alimentos, esporas artificiais, etc.). Eles só competem entre si em situações específicas, em rinhas menores feitas por eles, e para eles mesmos. Nas rinhas onde se encontram outras redes de relações, eles apenas cooperam entre si, fazem apostas conjuntas e cuidam dos seus animais coletivamente.

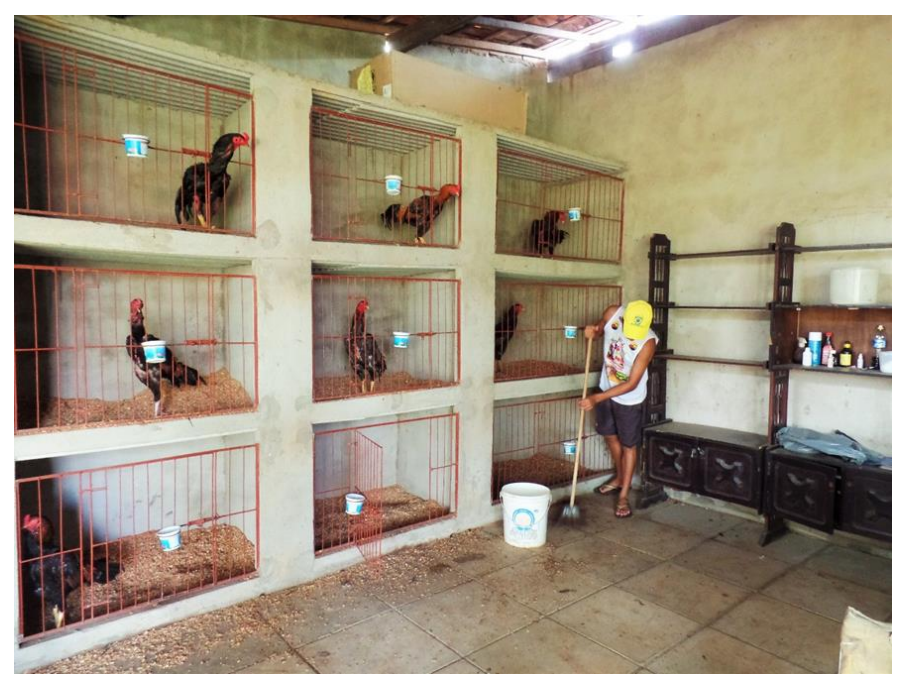

Imagem 2:Tratador realizando a manutenção do chiqueiro. Autoria própria (17/03/2015).

\footnotetext{
${ }^{14}$ Mixed Martial Arts.

${ }^{15}$ Todas as descrições feitas sobre os métodos de criação e treinamento são baseadas, principalmente, em uma criação específica, tida como modelo entre os galistas da região.
} 
$\mathrm{Na}$ vida desses galináceos existem três fases pontuadas pelos meus interlocutores: pinto, frango (ou franga) e galo (ou galinha). Para que um animal se torne apto às rinhas e passe a ter um cotidiano de atleta, leva-se, em média, um período de quatorze meses ${ }^{16}$, quando ainda é considerado um frango. Depois da primeira "muda" 17 e algumas brigas é que ele passa a ser um galo (adulto), com cerca de dois anos de vida. Muitos deles vivem mais de cinco anos em plena atividade nas rinhas, podendo chegar a pouco mais de dez anos, caso não morram de nenhuma doença ou por ataque de outro animal (cobra, por exemplo), nem percam a vida nas rinhas (o que não é fácil, mas não é impossível), nem cause uma grande decepção ao seu dono nas rinhas, que não hesitará em levá-lo para a panela. Geralmente, os que chegam a mais de dez anos, são bons galos que são aposentados das rinhas (entre 5 e 7 anos de carreira) para se tornarem reprodutores ${ }^{18}$.

A reprodução desses animais é feita a partir de uma verdadeira seleção genética de galináceos vencedores, numa busca incessante por um bom galo. As fêmeas usadas como reprodutoras ou matrizes, são escolhidas com base no seu parentesco com machos campeões. Via de regra, elas são sempre irmãs, mãe ou filha de um galo consagrado. A reprodução é realizada em um “chiqueiro de reprodução". Nesse local, nunca haverá mais de um galo e sempre haverá várias galinhas. Todas elas são fecundadas pelo mesmo galo, para que nasça uma geração de animais filhos de um mesmo macho e de fêmeas distintas. Apesar dessa herança patrilinear, os galistas afirmam que quem predomina é a raça da mãe. Em números, dizem que o animal herda vinte e cinco por cento do pai e setenta e cinco por cento da mãe, que está transmitindo as características de um campeão das rinhas.

Os ovos desses cruzamentos são levados para uma chocadeira elétrica, que simula as condições naturais de luz e temperara para que ovos possam ser chocados. Nascidos, os pintos são levados para uma espécie de berçário, como afirmou um dos meus interlocutores, chamado, também, de pinteira. Já nessa fase, eles são alimentados com milho triturado e com vitaminas específicas para o crescimento, que são colocadas

\footnotetext{
${ }^{16}$ É um processo relativamente demorado, principalmente se compararmos com os animais da indústria alimentícia que estão prontos para o abate sem atingir a fase adulta (em algumas granjas o ciclo vital é de apenas vinte e um dias).

${ }^{17}$ A "muda" consiste num processo fisiológico pelo qual o animal passa, em que todas as suas penas antigas dão, gradativamente, espaço a uma nova plumagem. Tal processo dura entre cinco e seis meses e acontece todos os anos na vida de um galináceo.

${ }^{18}$ Galináceos campeões das rinhas que deixam de combater devido à idade, mas que é mantido apenas para realizar cruzamentos para perpetuar seu sangue. Ele é também conhecido como matriz.
} 
na água. Já maiores, eles são colocados em outro local, quando começam a comer milhos. Quando viram frangos ou frangas (momento em que se distingue o sexo entre esses animais), eles vivem soltos nos quintais, se alimentando de ração específica para idade, pão, coco e outras coisas que encontram ao ciscar. Esse é o período de maior liberdade desses animais.

Com cerca de nove meses, os frangos machos começam a se "enterreirar", termo nativo que se refere ao momento em que um determinando animal altera seu comportamento e começa a brigar de maneira mais incisiva por território (daí o nome). Esse processo é o começo de sua transição para a maturidade, alcançada após a primeira "muda", que ocorre geralmente entre o décimo quarto e o décimo oitavo mês de vida.

A primeira "muda" marca o início da vida adulta do animal, que é consagrada nas rinhas, com algumas brigas. A "muda" pode ser lida como um "rito de passagem" (Van Gennep, [1909] 1978) que altera o status e o cotidiano do animal. Durante a "muda", acredita-se que o galináceo fica fraco e precisa de repouso, ou seja, ele não pode treinar, e muito menos, entrar nas rinhas. Nesse período, só é permitido ao animal reproduzir. Após essa primeira "muda", inicia-se a vida de atleta. Todo o cotidiano do animal agora é voltado para a sua performance nas rinhas.

Acredita-se que um galo não aprende a brigar, que ele briga por instinto. Segundo meus interlocutores, cada animal tem seu estilo de luta, herdado dos seus progenitores. Os métodos e técnicas de criação e treinamento, que se iniciam na fase adulta do animal, servem apenas para melhorar o preparo físico, aprimorar o rendimento e dar mais agilidade, tornando-os verdadeiros atletas. Nesse sentido, fica claro que não basta ser adulto para ser um galo de briga. Ele deve, necessariamente, passar por um processo de criação e treinamentos, o que implica dizer que um galo de briga só existe através da intervenção e da performance humana.

Quando adulto, o galo vive na "cocheira", que segundo afirmaram, é o apartamento desses animais, que pode ser visualizado na imagem 2. Esses espaços são higienizados constantemente e localizados na sombra. Usa-se pó de serra para que os animais não machuquem ou calejem seus pés, e para evitar a humidade, garantindo a absorção dos excrementos. É nessas “cocheiras” que esses galináceos são alimentados e hidratados. A alimentação desses animais consiste numa mistura rica em vitaminas e nutrientes, que se julgam necessários para a saúde e desempenho desses atletas: é um misto de milho triturado e legumes (cenoura, beterraba, couve, etc.). 
Fora das "cocheiras", os galos têm, cada um, separadamente, sua rotina de treinamento que inclui ficar nos "passeadores, pegar de mão e o tombo" ${ }^{19}$, além de banhos de relaxamento e escovações periódicas. Só após todo esse processo, que dura entre oito e doze semanas, é que um animal está pronto para combater ${ }^{20}$. Todos os treinamentos são inseridos de maneira paulatina no cotidiano dos animais, para não contundi-los nem fadigá-los. Os passeadores são os primeiros equipamentos de treino usados e perduram até o final da temporada. Na imagem abaixo, podemos ver três galos no passeador.

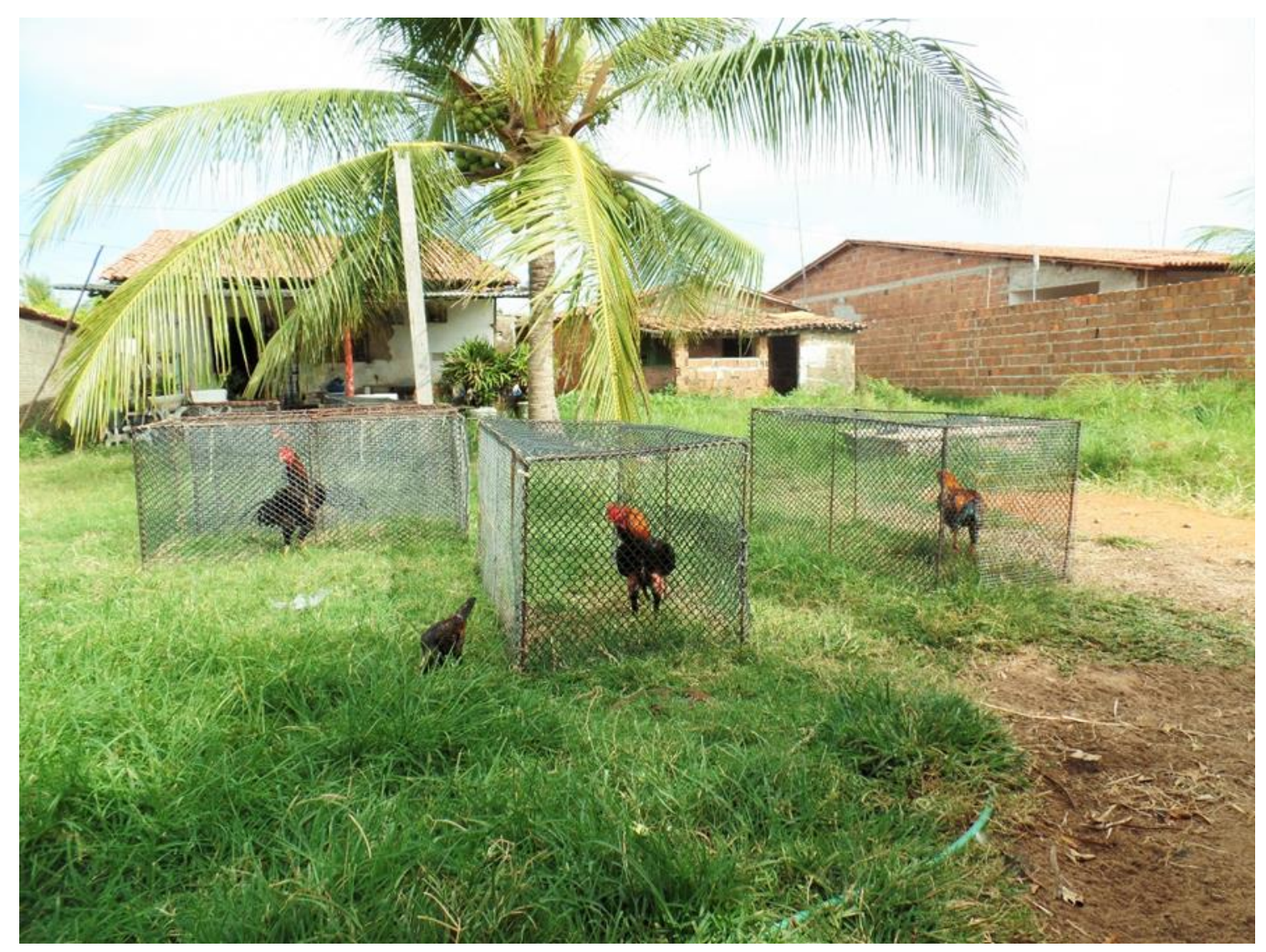

Imagem 3: Galos nos passeadores. Autoria própria (06/02/2015).

\footnotetext{
${ }^{19}$ Todas essas modalidades de treinamento serão explicitadas mais à frente.

${ }^{20}$ Vale dizer que nem todos os galistas seguem essa recomendação e colocam seus animais para combater antes do tempo recomendado. Alguns dizem que quem não respeita o tempo mínimo de oito semanas está maltratando seus animais. Devido a todo esse processo, num ano, um galináceo entra nas rinhas, no máximo, três vezes ou quatro vezes, se levarmos em consideração os cinco/seis meses de "muda" e os dois/três meses de preparação. Muitos deles lutam apenas uma vez, caso tenha tido uma luta dura e tenha se machucado bastante.
} 
Esses equipamentos garantem o banho de sol diário das aves, além de possibilitar o exercício de suas pernas. Os galos permanecem nos passeadores apenas no período da manhã, ao meio dia voltam para suas "cocheiras" e são alimentados, permanecendo lá até o período da noite, quando pode haver ou não outros exercícios, dependendo da fase de treinamento em que estão.

No período da noite, os animais, aptos, fazem o exercício chamado de "pegar de mão". Esse é um termo genérico que inclui uma série de exercícios físicos, os quais o treinador induz o galo a realizar. O "pegar de mão" é uma performance conjunta entre atleta e treinador. Este, utilizando seu corpo, principalmente as mãos (daí o nome do exercício), força o atleta a exercitar partes do seu corpo (pescoço, pernas, peito, asas). Tal treinamento é feito com bastante cuidado, apenas especialistas conseguem realizalo, já que os movimentos devem ser feitos de maneira metódica e introduzidos paulatinamente no cotidiano do animal. Os primeiros dias são com exercícios mais simples e com menor número de repetições. Com o passar dos dias vão se complexificando e aumentado em número e tempo. Esse exercício é realizado no chão, e, também, em mesas acolchoadas, específicas para isso. Ao final, os animais são massageados, medicados (caso precisem), escovados e levados para as suas "cocheiras" para, no dia seguinte, retornarem ao treinamento.

Por fim, existe o "tombo", que são treinos mais puxados, que só se iniciam no final da segunda semana de treinamento. O "tombo" é uma verdadeira simulação das rinhas, só realizado uma vez por semana, pois exige muito do animal. Devido essa dinâmica, a preparação do animal é também contada em "tombos". Para que um animal esteja apto a entrar nas rinhas, ele deve ter entre oito e doze "tombos" (semanas). É no "tombo", que os treinadores, de fato, conhecem seus atletas. É aí que eles sabem se o animal herdou o estilo de luta desejado dos seus progenitores, se ele se defende bem, se bate bem, etc. Nesses treinos, os galos são equipados com "biqueiras" e luvas emborrachadas para reduzir os danos causados. As "biqueiras" são colocadas em seus bicos, já as luvas são sobrepostas aos seus "batoques" (nomes dados na região para a espora natural do galo). 


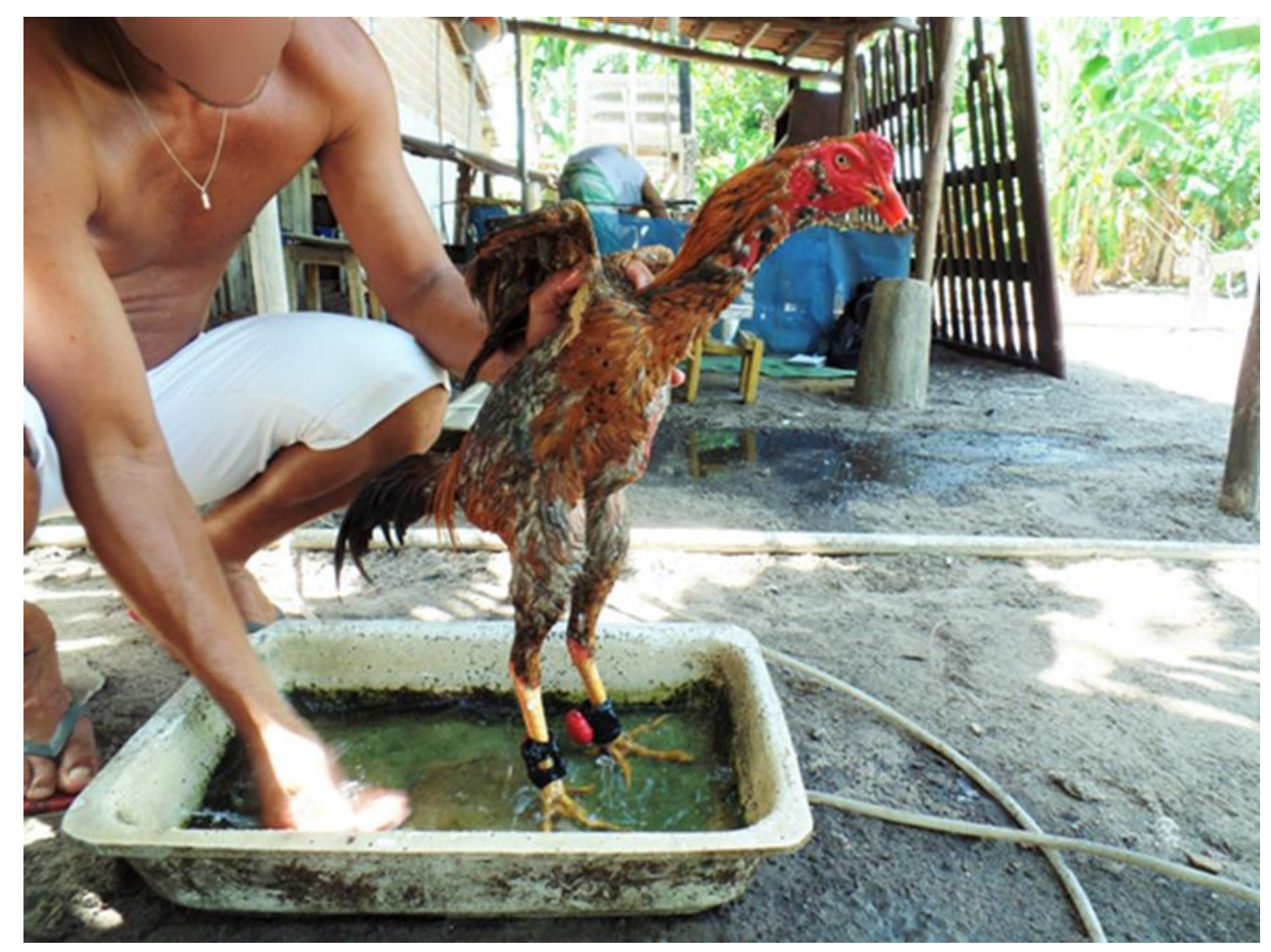

Imagem 4: Galo equipado com biqueiras e luvas, sendo banhado antes do tombo. Autoria própria (30/01/2015).

$\mathrm{Na}$ imagem anterior, podemos ver um galo sendo banhado e equipado para tombar. Os "tombos" semanais são verdadeiros eventos. Galistas de uma mesma rede de relações se juntam para treinar seus animais em um determinado quintal. Há sempre o consumo de bebidas alcoólicas e o clima de brincadeira e desafios é evidente, só que em menor escala, se compararmos a uma rinha. Nesses momentos, há uma importante troca de informações sobre experiências, técnicas de criação e treinamento. Outros assuntos valorizados no universo masculino local também entram em jogo, como: futebol, vizinhança, mulheres, MMA, casos de violência da região, etc. 


\section{A História de uma Criação: Protagonistas, Raça e Parentesco}

Tendo apresentado os métodos e as técnicas de criação e de treinamento, espero ter demostrado um pouco da complexidade desse universo. Acredito que tenha ficado minimamente claro como se faz um galo de briga, qual o seu cotidiano desde o nascimento até o momento das rinhas. Agora, falarei um pouco sobre a história de uma criação específica. Ao falar sobre os galináceos protagonistas de um determinado chiqueiro, espero explicitar a importância que se dá ao parentesco e a descendência na criação de galos combatentes - importância essa, expressa em termos como raça, traço e sangue.

Todo e qualquer galo de briga tem uma história familiar, uns prezam por ela e outros nem tanto. Os galistas de elite levam muito em consideração a descendência de cada animal. Isso porque, segundo esses criadores, a probabilidade de um galo se tornar campeão nas rinhas é maior se seus ascendentes também tiverem sido campeões. Portanto, um galo vencedor, considerado bom, que por algum motivo tem que parar de brigar (seja porque ficou cego, perdeu algumas disputas e/ou alcançou uma idade que não serve mais para as rinhas), tem grande probabilidade de se tornar um reprodutor, também chamado de matriz. Uma fêmea filha, irmã, ou mãe de um galo campeão, geralmente, também é escolhida como reprodutora. Desse modo, uma criação pode ser tida como uma verdadeira seleção genética de galos vencedores, com características desejadas pelos seus donos, que têm seus sangues (ou traços) perpetuados, numa eterna busca por mais um campeão, para se estabelecer uma nova raça.

Se tomarmos um exemplo específico e concreto, fica melhor para demonstrar como se pode iniciar uma criação de galos combatentes, como surgem novas raças, como são feitos os cruzamentos e como os humanos enxergam o parentesco entre animais. De antemão, afirmo que a classificação de parentesco usada é a mesma utilizada entre os humanos da região (como por exemplo: bisavô, bisavó, avô, avó, mãe, pai, filha, filho, sobrinho, sobrinha primo, prima), porém, não há relações de compadrio, nem interdições sexuais entre os galináceos. Não há incesto: todos os cruzamentos possíveis são válidos na busca por um bom galo de briga. 
Toda e qualquer criação de respeito se inicia com um galo de raça já consagrada. Existem inúmeras raças de galos consagradas e elas variam de região para região, no Brasil e, obviamente, de país para país. Se levarmos em consideração as diferenças morfológicas

... os galos geralmente são divididos em dois grupos: entre os banquivóides e os malaióides, os quais são subdivididos em raças e castas [que variam bastante de acordo com o lugar]. A diferenciação básica é o tamanho e a altura, enquanto os primeiros são menores e mais leves com média de $2,0 \mathrm{~kg}$ de peso, os segundos variam entre $2,5 \mathrm{~kg}$ a $4,0 \mathrm{~kg}$, com algumas raças chegando a $6,0 \mathrm{~kg}$.

Para além dessas diferenças básicas, o que cessaria com as exceções, os galos banquivóides caracterizam-se por ter plumagem mais densa, asas mais longas o que lhe proporciona voos maiores em relação aos malaióides (muito embora os galináceos não se destaquem em voos contínuos e longos, mas pelos voos rasantes), isso torna os banquivóides mais ágeis, no entanto, os malaióides são geralmente mais robustos, com musculatura mais densa. Esses detalhes, associados a um conjunto de projeções socioculturais, incidem diretamente sobre as formas como se dão os embates e a maneira como se cria cada uma das variedades para os combates (Corrêa, 2014: 203-204).

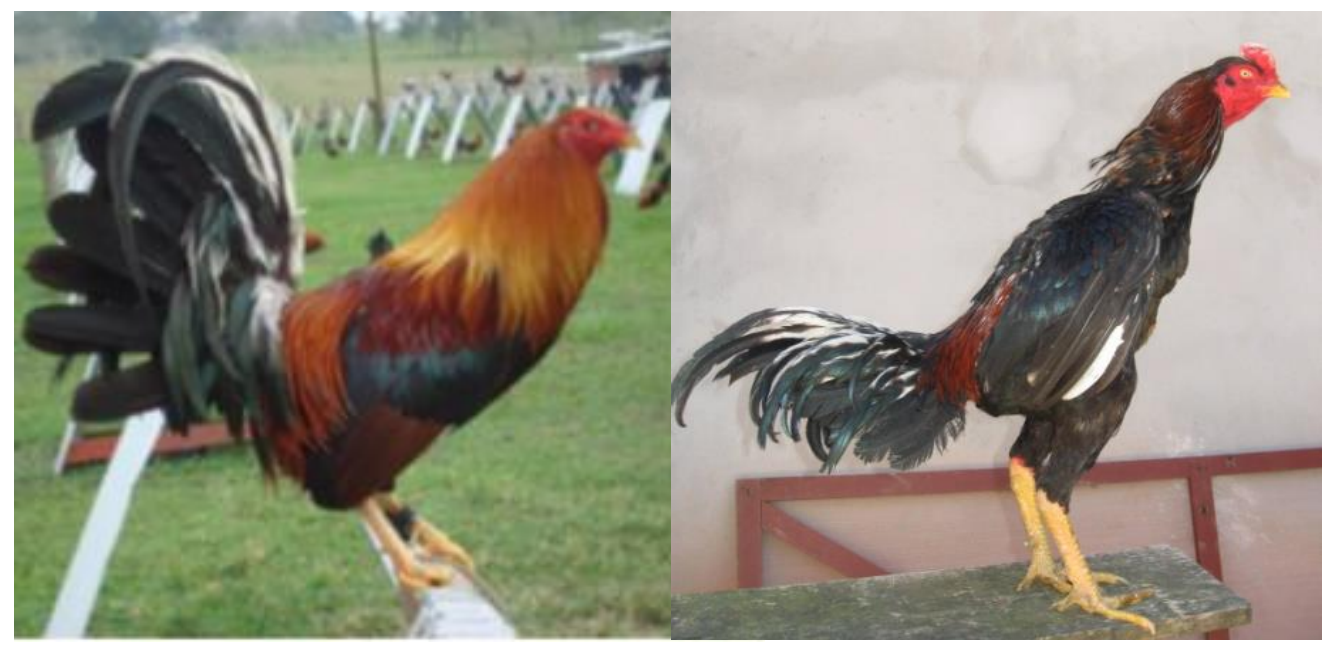

Imagem 2: À esquerda o galo Banquivóide. À direita o galo Malóide. Imagens retiradas do artigo "Alectoromanquia": os galos de briga na história ambiental (Corrêa, 2014).

Os galináceos utilizados, na grande maioria das rinhas brasileiras, são os Malóides, devido a sua agilidade e por proporcionarem combates mais prolongados. Os Banquivóides são os tipos utilizados na América Central, do Norte, Europa Ocidental e Bali, onde ocorrem combates de curta duração, com esporas em forma de navalha, bem diferentes às daqui apresentadas (Corrêa, 2012). 
Todas as raças que conheci no litoral norte paraibano são derivadas diretamente dos Malóides. Consegui catalogar as seguintes raças na região: "Cano Serrado", "Cacuruta" "China", “Coca", “Consanguíneo", “Gil”, "Mutran”, "Pouca Roupa", "Sucuri" e "Tulon". A maioria desses nomes diz respeito às características físicas desses animais, como é o caso do "Cano Serrado" (uma referência a sua espora), o "Pouca Roupa" (que diz respeito a sua plumagem) e o "China" (que se refere ao seu olho); outro, muito provavelmente se refere a sua agilidade, como é o caso do "Sucuri"; os demais não consegui coletar informações.

$\mathrm{Na}$ verdade, no que concerne ao termo raça, existem muitas controvérsias. Esse é um assunto rodeado de incertezas. Primeiramente, sabe-se que todas as raças são frutos de cruzamentos que em um determinado momento se estabeleceu como tal. Segundo, muitos galos que conheci na região, são identificados por mais de uma raça: "Sucuri com Coca", "Mutran com Tulon", e assim por diante. Terceiro, apesar de muitos desses nomes se referirem as características físicas desses animais, muitos deles não as possuem de fato (por exemplo, pode-se encontrar um galo "Tulon" com um olho mais "puxado" do que um galo "China"; ou um galo "Pouca Roupa" com menos plumagem que um galo "Mutran"). Creio que esses nomes se referem à origem, quando essas raças foram estabelecidas, existiam galos com essas características físicas, às quais os nomes aludem. Mas com o passar do tempo e com os diversos cruzamentos, isso se perdeu. Por fim, um dos interlocutores afirmou que os galistas não identificam com plena certeza as raças só de olhar. Deve-se conhecer o dono, que atestará sua raça por meio da palavra, demostrando sua genealogia. Com isso, podemos perceber que a credibilidade do dono nesse quesito é algo importante.

É interessante notar que essa credibilidade passa, também, pelo status social que a pessoa goza. Isso porque os únicos galistas que sabiam as raças dos seus animais eram os com maior poder aquisitivo. Um determinado galista indígena, com menos recursos, disse-me que

Raça é coisa de rico, meus galos não têm raça. Eles são galos criados por mim mesmo, que saio trocando, comprando, mas sem querer saber a raça. Quero saber é se o galo briga bem, se eu vê que ele é bom eu quero ele. Quero saber de raça não. Raça é coisa de quem tem dinheiro e quer aparecer. Meus galos são feitos aqui mesmo (Romário ${ }^{21}$, Interlocutor e Galista. Entrevista cedida no dia, 13 de março de 2013).

\footnotetext{
${ }^{21}$ Nome fictício.
} 
Essa preocupação, com um certo pedigree dos animais, é uma preocupação da elite galista. Criadores mais populares não têm esses registros. Interpreto que isso acontece, porque esses criadores com menos recursos não anseiam por estabelecer novas raças. Primeiramente, porque eles não têm recursos para tanto, segundo, porque não teria credibilidade para tal, já que para se estabelecer novas raças é necessário se ter uma criação de respaldo entre seus pares e, para isso, necessita-se muito investimento na estrutura da criação.

Todas as raças citadas aqui existem em mais de uma das criações que visitei. Isso porque elas são criações de amigos, que circulam seus galináceos entre si. Atestei que nenhuma dessas raças foi desenvolvida no litoral do norte paraibano, segundo informações, todas elas vêm de fora (de outras regiões da Paraíba e de outros Estados). Para se saber, ao certo, a genealogia dessas raças é necessário um trabalho de maior abrangência, que inclua outras regiões da Paraíba e até de outros Estados. Isso, porque, no que concerne ao tema raça existem muitas controvérsias, como já falei. Com certeza, existem outras raças na região não catalogadas aqui. Foi-me dito que outros criadores dizem ter outras raças, mas que não se sabe ao certo se isso é verdade ou não. Mas que é bastante provável, afinal, outras redes de galistas, com seus contatos, podem trazer outros animais de outros locais.

De fato, pude notar com leituras, conversas em campo e pesquisas na internet que as raças não são um consenso entre os galistas das diferentes regiões do Brasil e do mundo, pois em cada região pode haver o surgimento de uma nova raça, derivadas de cruzamentos genéticos nas mais diversas criações existentes por aí a fora. Segundo me informaram, essas raças são nomeadas pelos próprios criadores que conseguem estabelece-las. Na região estudada, não há uma raça exclusiva, ainda. Todas as existentes vieram de fora, como é o caso da criação que mostrarei, que ainda não conseguiu estabelecer uma nova raça, mas que seu dono anseia por isso.

Só para se ter ideia da nebulosidade do tema, em conversas informais, perguntei a um interlocutor se essas raças que eu estava conhecendo ali existiam em todo Brasil, e ele me disse que não sabia, mas que provavelmente não, pois ele já havia ouvido falar de raças que nunca viu em sua região, que dizem ser exclusivas de outros locais, como por exemplo no Sul do país. A região Sul do Brasil é um lugar conhecido por ter raças 
exclusivas e que é considerada, por muitos galistas do Brasil, como a principal região do galismo nacional, onde há as melhores criações e os melhores galistas ${ }^{22}$.

Questionei meu interlocutor como é que se dá o surgimento de uma nova raça, e foi me dito que é através de muitos cruzamentos de raças já existentes, e que o criador deve ter uma criação já antiga com galos vencedores e com características únicas e reconhecidas por seus pares. Isso demostra que o surgimento das raças respeita uma certa dinâmica própria ao universo do galismo, que implica um reconhecimento social e respaldo dos seus pares. Nesse sentido, apenas um galista com muitos cruzamentos efetuados (o que implica em anos de criação), sucesso nas rinhas e o reconhecimento dos outros é que pode nomear uma nova raça. Não conheci nenhum galista em campo que tenha estabelecido uma nova raça. Mas conheci um que anseia por isso: Zé Firmino.

Sua criação tem mais de seis anos de existência. Quando ela teve início, Zé Firmino já era um galista reconhecido, porém não tinha uma criação reprodutiva, apenas bons galos de briga. Foi frequentando as rinhas, fazendo amizade e sendo reconhecido por bons galistas que ele recebeu uma dádiva de um amigo das rinhas: um galo reprodutor que já não brigava mais, uma matriz, um galo vindo da cidade de Alagoa Grande-PB. O galista que lhe deu esse presente já era reconhecido pela sua criação e por desenvolver galos únicos, segundo o que me foi dito, por já ter estabelecido uma raça. Esse presente foi dado, o galo veio "sem raça", para que o seu novo dono estabelecesse novas cruzas para buscar uma nova raça e se firmar na Baía da Traição com sua criação. Essa dinâmica revela que a dádiva e a reciprocidade (Mauss, [1925] 1974) são coisas fundamentais no universo das rinhas.

A partir de então, é que Zé Firmino começou a sua busca por uma boa galinha para fazer seus cruzamentos e iniciar sua criação. Ele adquiriu algumas, outras ele ganhou de amigos e, desde então, não para de fazer seus cruzamentos, tendo se estabelecido como o melhor criador de galos da Baía da Traição, apesar de ainda não ter uma nova geração de galos campeões com características próprias, ou seja, uma nova raça. No diagrama de parentesco a seguir, podemos ver a criação e os cruzamentos dos galináceos do quintal de Zé Firmino.

\footnotetext{
${ }^{22}$ Sobre o galismo no Sul do Brasil ver o "De Homens e Galos: um estudo antropológico sobre "um jogo absorvente' na região central do Rio Grande do Sul” (Silva, 2011). Apesar desse autor não trazer em seu trabalho uma apresentação ou discussão das raças em seu contexto etnográfico, a partir da sua leitura, podemos ver que o galismo na região que ele estuda é bem mais elitizado que o do litoral norte paraibano.
} 


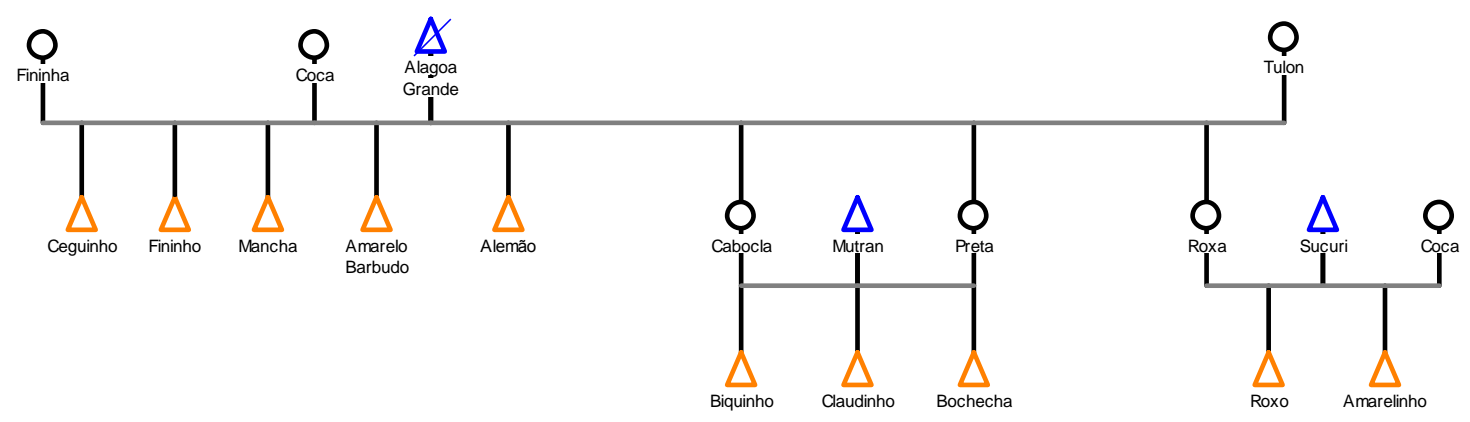

Imagem 6: Diagrama de parentesco da criação de Zé Firmino, construído com a ajuda do tratador.

O galo matriz “Alagoa Grande”, em azul, hoje em dia morto ${ }^{23}$, foi o que deu início a sua criação. Podemos ver que Zé Firmino adquiriu três galinhas para cruzar com ele. O primeiro cruzamento foi com uma galinha chamada Fininha, que não se sabe a raça e que foi uma dádiva de outro criador. Desse cruzamento saíram três galos machos: "Ceguinho", "Fininho" (seu principal galo) e "Mancha". Do cruzamento com uma galinha da raça "Coca", nasceu o galo "Amarelo Barbudo". Da cruza com uma galinha da raça "Tulon", nasceu o galo "Alemão" e três fêmeas que logo assumiram o papel de reprodutoras, para perpetuar o sangue do galo "Alagoa Grande".

A partir da morte do galo "Alagoa Grande", o dono dessa criação adquiriu mais dois galos reprodutores: "Mutran" e "Sucuri" (representados como a matriz principal também em azul por serem reprodutores). Ambos os novos reprodutores cruzaram com as filhas da matriz principal, que deu início a criação. Dessas novas cruzas nasceram mais cinco galos que hoje em dia já são atletas das rinhas: "Biquinho", "Claudinho", "Bochecha", "Roxo" e "Amarelinho" - todos esses "netos" do galo de "Alagoa Grande".

Desses cruzamentos nasceram mais outros galos, porém os citados foram os únicos que permanecem na criação de Zé Firmino. Os outros que não constam no diagrama foram vendidos ou dados a amigos. Alguns poucos morreram. Outros cruzamentos foram realizados e novos animais estão nascendo, porém, como não se sabe ainda o futuro dos mesmos, escolhi representar apenas os animais que já estão nas rinhas, que já deixaram a categoria de frango e estão vivendo a vida de atleta. Com isso, espero ter demonstrado a importância do parentesco nas rinhas e como surge uma nova raça (e que esse é um tema que demanda mais pesquisas).

\footnotetext{
${ }^{23}$ Morte indicada pelo traço diagonal que corta o triângulo que o representa.
} 
Nota-se que, de maneira geral, os galináceos (machos e fêmeas) são identificados pela raça ou por um nome próprio que lhes é conferido pelos seus donos. Essas duas formas de identificar os animais podem nos indicar uma série de questões. Para pensarmos sobre isso, vale citar aqui o capítulo intitulado "Nomear como Contar Histórias: falando de animais entre os Koyukon do Alasca", do livro "Estar Vivo: ensaios sobre movimento, conhecimento e descrição", de Tim Ingold (2015). Nesse referido capítulo, tal autor contrasta certos modos de nomeação e classificação das sociedades ocidentais com as lógicas de nomeação que os Koyukon conferem aos seus animais.

De acordo com Ingold (2015) no ocidente existem duas maneiras de classificação predominantes: uma que singulariza o referente, que são os "substantivos próprios" (ou "nomes") que são usados quase que exclusivamente para humanos, com exceção de alguns animais de estimação; e outra generalizante, que são os "substantivos comuns" (ou "apelativos") e que são usados para os "animais selvagens", as plantas e outras coisas. Essa distinção tem sua raiz na separação natureza x cultura, que postula a separação da sociedade humana do domínio da natureza e coloca os humanos como indivíduos únicos em oposição a uma "natureza" genérica. O humano (cultura) é identificado por um "nome" que lhe confere singularidade, agência, história e lugar no mundo. Já os animais, plantas e coisas são rotulados por um "apelativo" que apenas o categoriza de maneira generalizante.

Nesse sentido, podemos compreender a raça como um "apelativo" das rinhas. Apesar de ser menos genérico do que os termos como "animal", "galináceo", "galo", "galinha", qualquer termo utilizado para designar uma raça ainda se refere a uma classe dentre esses animais, classe essa que demonstra que ele é mais um dentre os seus, com aquela genética. Já os nomes próprios que lhes são conferidos, são singulares, assim como os nossos. Nesse sentido, podemos compreender que eles, apesar de distintos, possuem certas semelhanças com os humanos que partilham o mundo com tais animais. Pois, segundo Ingold (2015).

Ser propriamente humano, aos olhos ocidentais, é, portanto, ser uma pessoa com identidade única, nomeada, e ocupar um lugar específico, nomeado, de acordo com certos princípios de aquisição. Trata-se, em suma, de ter um nome e um endereço. Um ser humano sem nome ou endereço é um vagabundo ou fugitivo, um "homem selvagem", excluído da sociedade e reduzido de fato a uma existência animal. Por outro lado, através da atribuição de nomes e endereços a animais os introduzimos em nossas casas como companheiros quase humanos (Ingold, 2015: 244-245). 
Apesar de poderem argumentar que a citação acima se refere aos "animais de estimação", que compartilham o interior da nossa casa conosco e, que os galináceos vivem nos quintais, não podemos negar que os seus criadores têm uma estima pelos mesmos e que lhes confere agência, endereço e singularidade. Pensando nisso e em alguns comentários que ouvi em campo, é inegável, que para os galistas, esses animais têm agência e são alocados no tempo e no espaço humano, ou seja, participam dos que muitos chamam de "cultura". Afirmo isso, pois já me foi dito em campo coisas do tipo: “esses animais pensam", "quando um não quer brigar não briga". Além do mais, não há como negar que a performance desses animais influencia seus "donos", o humor dos mesmos, de tal maneira que se acredita, em certa medida, na agência do animal, mesmo que essa não se compare a dimensão da agência humana, que é de outra ordem.

O citado texto de Tim Ingold (2015) nos faz pensar também sobre a lógica que está por trás das escolhas dos nomes dos galos de briga. Isso porque em seu texto, esse autor, apoiando-se em textos etnográficos, fala que entre os Koyukon do Alasca existem formas de nomear os animais que diferem da lógica ocidental que opera com o uso de substantivos. De acordo com Ingold (2015), os Koyukon nomeiam os animais não humanos baseando-se em três coisas: "descrição do comportamento do animal observado", as "histórias míticas da criação do mundo" e a partir de "enigmas". Esses três modos de nomeação não são excludentes entre si, ou seja, existem nomes que se baseiam em uma, duas ou três dessas lógicas. Todas elas exprimem uma ação, seja atual, seja na história mítica (quando apenas havia seres míticos, distinto tanto dos humanos quanto dos animais), seja através de enigmas que se referem ao comportamento do animal. Nesse sentido, Tim Ingold conclui que nomear os animais entre os Koyukon é um ato de verbalizar suas ações.

Para findarmos essa discussão, afirmo que no contexto etnográfico que aqui descrevo existem formas de nomeação substantivadas e verbalizadas, que seguem a lógica ocidental, mas também que são de outra ordem. De maneira geral, a nomeação dos galináceos é baseada em algum traço do seu fenótipo (característica física expressada), em algum comportamento observado e até em signos e símbolos que expressem força, agilidade ou violência (características valorizadas nas rinhas). O caso de "Fininho", por exemplo, é um nome que expressa essas três lógicas: é um nome que expressa seu biótipo (magro), seu comportamento e sua agilidade. Outros animais são chamados de "Matador", "Furador", "Sangrador" - nomes que expressam verbos, ações. 
Outros são chamados de "Perna Branca", "Roxo", "Alemão", por referência a sua coloração.

\section{As Rinhas e o Contexto Interétnico}

O fato mais característico do contexto sociocultural do litoral norte paraibano é o contato histórico e atual entre índios da etnia Potiguara e populações não indígenas desde tempos mais remotos da colonização brasileira. Nesse contexto interétnico ocorre simultaneamente uma "hibridização cultural" (Canclini, 2006) e uma produção de fronteira étnica que divide a população, hoje em dia, de maneira genérica entre "índios/caboclos" e "brancos/particulares" ${ }^{24}$. Nas rinhas que participei, a hibridização cultural é um processo mais visível, já a demarcação de fronteiras étnicas me pareceu borrada nesses encontros de lazer, sendo acionadas apenas em algumas situações específicas.

A estrutura social local é bastante ambígua, difusa e difícil de delinear. É uma região de conflito (principalmente territorial) entre índios e não índios: no processo histórico os indígenas foram usurpados de suas terras, mas atualmente têm conseguido recuperar certas localidades através do autorreconhecimento e da mobilização política deles, que tem sua maior expressão na dança do Toré ${ }^{25}$. É também um lugar de associação e alianças entre índios e não índios: além de existirem aliados não indígenas na luta política, existem, também, empreendimentos privados feitos a partir da interação interétnica (carcinicultura, pousadas, bares, etc.). É uma região marcada por uma história sangrenta, de traumas coletivos, mortes e disputas, mas também fortemente

\footnotetext{
${ }^{24} \mathrm{O}$ termo caboclo é uma categoria fruto do processo de contato entre as populações locais e a sociedade envolvente (Colônia, Império e, posteriormente, República). Já o termo índio passou a ser utilizado a partir do contato dessa população com o órgão indigenista (SPI/FUNAI) e se refere ao campo dos direitos jurídicos. O termo particular também foi fruto desse processo com o órgão indigenista, que passou a classificar juridicamente os não índios da região que estabelecem relação matrimonial com indígenas. $\mathrm{O}$ termo branco é usado hoje em dia pelos indígenas para classificar os não índios de maneira geral. (Palitot, 2005a; Vieira, 2012).

${ }^{25}$ O Toré é a manifestação mais emblemática da identidade étnica do que se convencionou chamar de Índios do Nordeste. Na obra "Toré: regime encantado do índio do Nordeste", Rodrigo Azeredo Grünewald (2005) caracteriza essa "dança" como uma fato social total, ou seja, como uma prática que envolve e é composta por diversos âmbitos da vida sociocultural das populações indígenas, como: as dimensões do sagrado/profano, do lazer, da economia, identitária, histórica, política, etc. Apesar de ser um fenômeno "multissemântico", difícil de generalizar devido as suas particularidades com que ele se apresenta em cada população indígena, podemos caracterizá-lo como uma performance política que expressa a etnicidade das populações indígenas do Nordeste. Ainda nessa obra, temos o artigo de Palitot (2005b) intitulado "Todos os Pássaros do Céu: o Toré Potiguara", onde podemos encontrar algumas das especificidades dessa prática dentre os Potiguara-PB.
} 
conhecida pelas suas festividades (carnaval, festa de santos), pelo turismo no veraneio, pelo lazer, por práticas esportivas e pelo lúdico.

Posso afirmar que todos esses aspectos do contexto sociocultural se encontram nas rinhas de galos, que apesar de ser um evento situado às margens da estrutura sociocultural local, dialoga fortemente com ela, seja criticando-a, reforçando-a ou (re)criando-a. A rinha de galos é um verdadeiro microcosmo que reflete o macrocosmo sociocultural. Porém, tal reflexo não é exato, é difuso, pois ao mesmo tempo em que põe em xeque, também reforça a ordem estrutural, seus signos e símbolos.

As rinhas podem, inclusive, nos dizer muito sobre o processo de criminalização e estigmatização que os povos indígenas passam, processo esse que é fruto da interação com os não indígenas. Digo isso porque o surgimento e crescimento das rinhas nas áreas indígenas são, relativamente, recentes. Segundo alguns anciões com quem conversei informalmente, não existiam rinhas nas aldeias quando eles eram jovens. Um interlocutor indígena, que é considerado como um dos galistas mais antigos e atuantes, afirmou que há cerca de 25/30 anos só havia "umas briguinhas debaixo de pé-de-pau. Não existia essa coisa que tem hoje". Ainda segundo ele, as coisas foram se organizando conforme alguns indígenas foram conhecendo as rinhas de fora, dos "brancos". Ou seja, a prática do galismo não era especializada como hoje, não era um esporte, era uma atividade menos recorrente realizada por alguns, sem muita estruturação e conhecimentos envolvidos. Com certeza, o número de rinhas cresceu na área indígena devido ao envolvimento de indígenas com não índios, mas também devido ao crescimento da fiscalização nas áreas urbanas da região, que cada vez mais faz com que as rinhas passem a ser realizadas com mais segurança dentro das aldeias, onde estão os lugares mais ermos da região e a fiscalização é menos efetiva.

Um dos meus interlocutores, considerado como um dos galistas indígenas mais antigo e grande fomentador da atividade na região, questionado sobre como ele se iniciou na briga de galos, respondeu o seguinte:

- Comecei através do meu avô, dos meus tios, né? Tinha um marido da minha tia, por nome de Adelino, que ele se tornou um representante de Baía da Traição de muito prestígio com galo. Então eu acompanhei. Eu ia nos quintais dele... Gostei, né?

- Ele era Índio?

- Era não. Quem era índia era a mulher dele, que era minha tia. Ai começou a se espalhar. Começamos a brigar... Ia pra os pau... A gente como índio ia pra dentro dos mato botar os galos pra brigar. Depois começou a entrar o povo branco nas 
aldeias e começou a convidar nós índios pra ir pra esses outros cantos conhecer. Eles com condições mais do que a gente... Que os negócios que a gente fazia, as briga da gente, a gente fazia de rolo de coqueiro. Um quadrado com rolo de coqueiro, que nem fazia chiqueiro pra porco. Cobria com um colchão e botava um tapete em baixo e botava os galos pra brigar. Isso nas aldeias. Ai comecemos a ir pra essas cidades maior. Começamos a ver as rinha de alvenaria, começamos a fazer ai essa rinha de alvenaria e hoje em dia tá assim as briga de galo. Quase todas as aldeias têm. Eles me chamam pra ir pra esses canto porque eu fui um dos primeiro em Baía da Traição a fazer esse esporte de briga de galo. Fui eu! Eu fui o primeiro descendente daqui que fiz rinha pra briga de galo, fui eu! Depois conheci Fulano e Beltrano... (Romário, Interlocutor e Galista. Entrevista cedida no dia, 13 de março de 2013).

Tal depoimento revela os laços de parentesco entre índios e não índios, e como tais laços ajudaram a configurar essa prática como hoje se apresenta. Foi a partir do convite de não índios que indígenas começaram a realizar rinhas mais estruturadas nas aldeias. Outros interlocutores dessa pesquisa disseram que colocavam animais para brigar sem nada, sem esporas, sem rinhas, sem rolos de coqueiro, colchão ou o que quer que seja, apenas debaixo de uma árvore. Outros me falaram que na infância chegaram a colocar pregos no lugar das esporas dos animais para deixar o combate mais excitante.

As rinhas são verdadeiros ritos "liminóides" (Turner, 2012). Este conceito diz respeito a fenômenos sociais presentes em sociedades complexas que foram afetadas pelos processos da Revolução Industrial. No caso do locus dessa pesquisa, se refere a todo o processo de transformação econômica pelo qual passaram as populações indígenas inseridas em áreas de contato mais intenso, como é o caso dos Potiguara. Com esses processos históricos, surgiu o "desencantamento do mundo" e a esfera do trabalho passou a ter uma autonomia, engendrando a ideia de lazer, um campo também autônomo que se colocou em oposição ao universo do trabalho, ou seja, como uma antiestrutura. São essas novas instâncias de lazer, brincadeira, que se encontram nos interstícios da estrutura social normativa, que Victor Turner quer compreender com o conceito "liminóide".

Dizer que a rinha de galos é um evento "liminóide" implica afirmar que é um rito que ocorre sob o signo do lazer, da brincadeira, onde há a mercantilização do entretenimento, a não obrigatoriedade de participação dos indivíduos e que ocorrem às margens dos processos centrais de produção social. Todos os eventos "liminóides" são ritualizados, performatizados e "ganham espaço nas margens e nas dobras de sistemas culturais estabelecidos, fora de mão, em más vizinhanças e áreas rurais remotas" (Schechner, 2012: 68) - o que é justamente o caso da briga de galos. 
Nesses espaços liminóides, existem uma importante característica: a existência de laços de communitas (Turner, 1974). Esses laços sociais antiestruturais se dão de maneira horizontal, sem levar em consideração, pelos menos, no momento em que acontecem, a verticalidade hierárquica da estrutura social. É como se houvesse a suspensão dos papeis sociais e as pessoas interagissem sob o signo da igualdade. Na rinha de galos um dos principais aspectos que promove isso é a ilegalidade da atividade. Perante a lei, todos ali estão cometendo um crime, não importa se são índios ou não índios, ricos ou pobres, policiais ou desempregados. Ouvi uma máxima em vários momentos que afirmava que a rinha de galos era democrática e que era um esporte sem preconceito, onde se têm ricos e pobres, onde "um mendigo pode ganhar de um juiz", como afirmou um de meus interlocutores. É nesse sentido que a rinha de galos é antiestrutural, pois ela, de certo modo, suspende a hierarquia de estratificação social e as fronteiras étnicas locais por um momento específico, dando chance a quem está "em baixo" vencer quem "está em cima".

Desse modo, como já foi dito, há nas rinhas uma suspensão das fronteiras étnicas que só em alguns momentos são acionadas. A rigor, não existe diferenciação entre os galos de índios e os nãos índios. O que existe claramente é uma diferença de classe social que se encontra associada às questões étnicas. Pude notar que, de maneira geral, os indígenas têm menos condições de criar galos, ou seja, os não índios são donos das melhores criações da região. É claro que existem exceções, que há índios que têm criações melhores que certos não índios. Mas, o fato é que os melhores chiqueiros da região são de não índios. Porém, conheci ótimos galistas indígenas que por vezes, apesar de não terem muitos recursos, superam os galistas mais abastados e se destacam com seus conhecimentos sobre esse esporte. Nesse caso, fica evidente o caráter "liminóide" das rinhas, a possibilidade de subverter a ordem estrutural do mundo cotidiano.

Há, porém, alguns símbolos étnicos que estão presentes nas rinhas, como é o caso da denominação galo caboclo, dada a qualquer galo de coloração marrom levemente avermelhada, seja ele de um indígena ou não (ver na próxima imagem). Quando ouvi tal denominação pela primeira vez, logo questionei um interlocutor: "É galo caboclo por que? É galo de índio?". Ele logo respondeu: "Não tem nada a ver, é por conta da cor do galo mesmo. Só isso". 


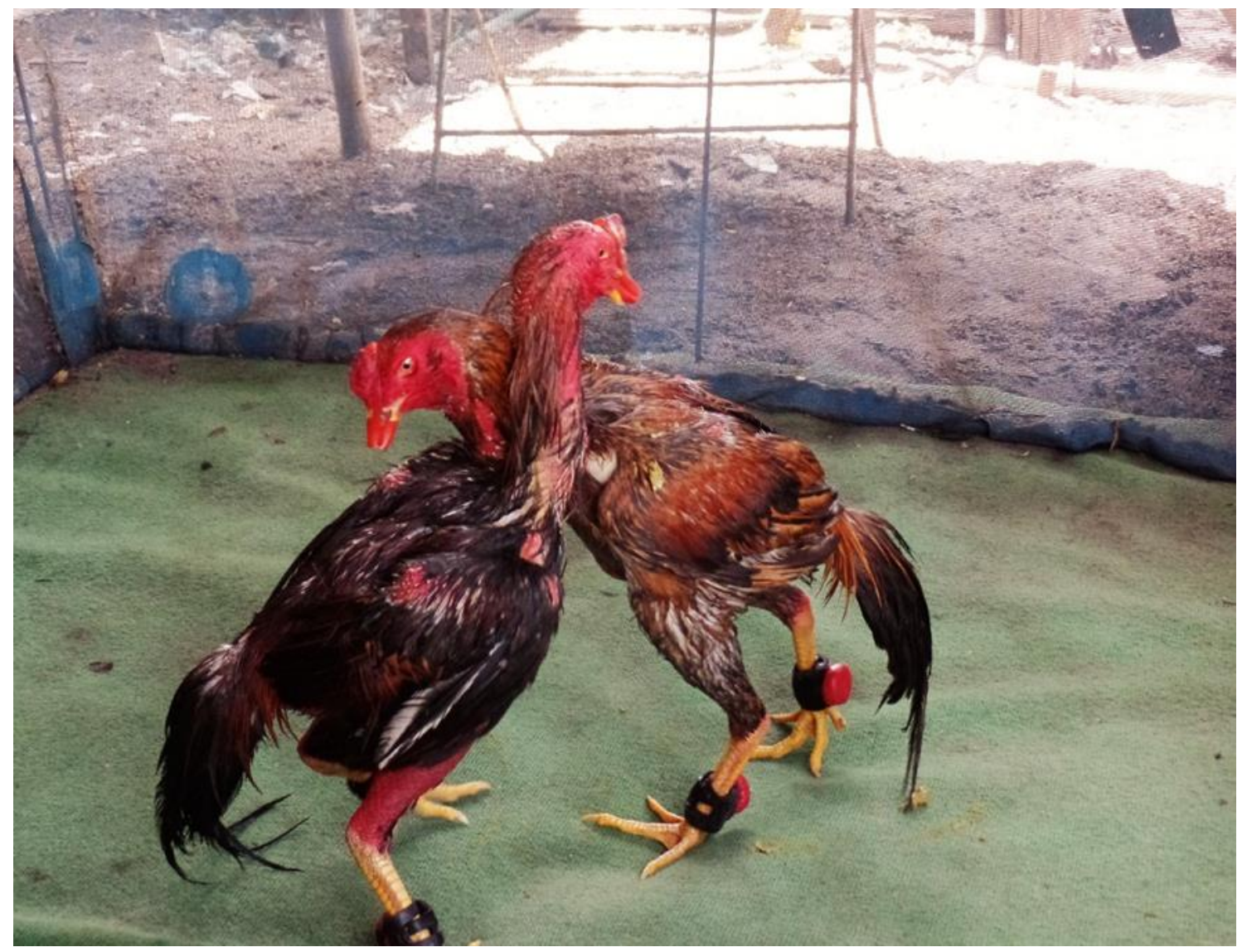

Imagem 7: Tombo ente um galo preto (à esquerda) e um galo caboclo (à direita). Autoria Própria $30 / 01 / 2015$.

O termo caboclo é um demarcador de identidade étnica na região. Dizer-se caboclo, onde índios se pensam como misturados, é se afirmar indígena. Esse termo é usado para se referir a certo grupo de indivíduos que possuem certa tonalidade de pele, certo jeito de andar e falar, reconhecidamente, caboclo na região. Ou seja, é falar daqueles com o fenótipo mais parecido com seus antepassados indígenas. Nesse sentido, podemos perceber que há uma associação entre animais humanos e não humanos, que leva em consideração questões fenotípicas.

Alguns indivíduos das rinhas usam a denominação "galo de índio" ou "galo de índio original", em oposição a "galo de laboratório" ou "galo de branco". Essas denominações surgiram apenas em situações específicas e eram acionadas por poucas pessoas. Notei que nas situações que essas expressões foram acionadas, era sempre por parte de um galista indígena, com poucos recursos, que enfrentava um adversário (indígena ou não) com condições financeiras melhores. 
Um indivíduo em especial sempre trazia essas expressões à tona: Romário - um indígena pescador de baixa renda apaixonado pelo galismo, um dos principais fomentadores das rinhas nas aldeias, que ajudou no desenvolvimento do galismo na região, mas que hoje em dia é considerado um galista desatualizado por não criar seus animais com rações especializadas, vitaminas e outros métodos e técnicas que só o dinheiro propicia. Segundo Romário, "galo de índio é um galo criado sem remédio, sem essas frescuras dos brancos, da maneira mais natural, no terreiro comendo milho”. Já "galo de laboratório" (“de branco") é um animal que é criado com uso de fármacos, vitaminas, comidas especializadas, num local todo higienizado, etc. "Cheio das frescuras", como afirma ele. Percebi que essas denominações eram acionadas nos momentos de derrota e vitória por Romário, sempre que ele enfrentava um galista (índio ou não índio) com melhores condições financeiras para criar seus animais.

Romário ao enfrentar seus adversários índios e não índios, afirma com orgulho que seu "galo é de índio", "natural”, "original”, que "não é galo de quintal de laboratório", "que seu galo ganha quando é bom, né por conta de comprimido não". Isso acontecia porque ele é um galista "a moda antiga", saudosista com seu tempo e que, apesar de ser um ator importante no desenvolvimento do galismo na região, enquanto um esporte, é crítico de uma série de práticas que ocorrem hoje nas rinhas e que desfavorecem os que não têm tantas condições financeiras, como o dopping, por exemplo. Nesse sentido, ele traz em seu discurso esse demarcador étnico para falar da desigualdade de classe nas rinhas, que se reflete também numa desigualdade étnica.

Com isso, podemos perceber que mesmo nas rinhas, apensar de não ser algo generalizado, de ser algo pontual e raro, a fronteira étnica é situacional e relacional (Barth, 2000). Ela só é acionada explicitamente em determinados contextos, por determinados atores e em resposta a determinados atores.

\section{Performances Ritual: Jogo, Disputa e Masculinidade}

Mesmo proibidas, as rinhas ocorrem com uma frequência semanal, de maneira formalizada, com um tempo e um espaço específico, um conjunto de regras partilhadas, que norteiam os acontecimentos e se constituem como eventos que constroem e expressam a vida individual e coletiva dos que dele participam, ou seja, é um evento ritual. 
De acordo com Richard Schechner (2012), os eventos rituais se dividem em sagrados e seculares. Os do primeiro tipo são aqueles ligados às práticas religiosas, já os de segundo tipo são aqueles associados as "cerimônias de estado, vida diária, esportes e qualquer outra atividade não especificamente de caráter religioso" (Schechner, 2012: 54). Tal divisão é analítica, pois existem cerimônias que mesclam elementos seculares e sagrados no processo ritual: casamentos, comemorações de São João (muito festejadas no Nordeste brasileiro) - ambas têm eventos religiosos (cerimônias) e profanos (festividades).

As rinhas aqui descritas são eventos exclusivamente seculares, até por que são encarados como uma prática esportiva por seus participantes. Os indivíduos frequentam tais ritos para brincar, se divertir, apostar, jogar e beber. Não há nesses espaços nenhum envolvimento com questões sagradas, como há na rinha de galos balinesa onde os galos são comumente associados aos "os poderes das trevas", onde "... qualquer briga de galos, é, em primeiro lugar, um sacrifício de sangue oferecido aos demônios, com os cânticos e oblações apropriadas, a fim de pacificar sua fome voraz, canibalesca" (Geertz, 1978: 287). Isso faz da briga de galos balinesa um evento ritual secular permeado por elementos religiosos, o que não é o caso das rinhas paraibanas. As únicas menções a elementos sagrados nos momentos das rinhas, partiram de indivíduos que colocam em jogo suas crenças particulares, para torcerem por seus galos e, mesmo assim, esses atos me pareceram mais um vício de linguagem do que propriamente uma crença (“Ahh meu Deus, vai galo!”, “Meu Jesus, esse galo é um fenômeno!”). Subjetivamente, alguns indivíduos fazem promessas para que seus animais vençam os combates, mas isso cabe a cada um. Outros preferem não envolver religião. O fato é que não existe uma associação entre essas rinhas e questões religiosas coletivas, como em Bali.

Segundo Schechner (2012), “performances - sejam elas artísticas, esportivas ou da vida diária - consistem na ritualização de sons e gestos [...] que são duplamente exercidos, codificados e transmissíveis [...] [um] comportamento ritualizado condicionado/permeado pelo jogo" (Schechner, 2012: 49). Nesse sentido, todo ritual pode ser tido como uma performance sociocultural de ações codificadas e transmissíveis e que envolvem atos fictícios, ambíguos e/ou a brincadeira. O conceito de performance dá realce a essas ações, que no contexto da briga de galos pode ser visualizada nas posturas, gestos, sons e palavras dos indivíduos nas rinhas. 


\title{
Segundo Rita Neves,
}

\begin{abstract}
$\mathrm{Na}$ performance, o comportamento é intensificado e exposto publicamente, substituindo eventos reais. As performances se efetuam nos momentos de interrupção da ordem social, ou seja, nos momentos de liminaridade. A performance contém aspectos caracterizados por repetição e ritmo, o que não significa que ela seja um texto fixo; ao contrário, sua característica é ser dinâmica, com capacidade para apontar aspectos reais da vida como a violência, a sexualidade, etc. (Neves, 2005: 176-177).
\end{abstract}

Nesse sentido, olhar a rinha como performance é realçar o ritmo das ações repetidas, porém, dinâmicas que se relacionam com a realidade da vida cotidiana, com o contexto social. Desse modo, tal rito (qualquer rito) pode ser lido como uma sucessão de ações individuais e coletivas realizadas em diálogo, com um determinado contexto (cultural local, regras do rito, signos e símbolos) que serve como pano de fundo que dá sentido a essas ações. Sabe-se que um ritual implica uma série de comportamentos previsíveis e novos, que são lidos pelos seus participantes, levando-se em consideração o contexto em que estão inseridos. São esses comportamentos que chamo aqui de performances. Já o "jogo" diz respeito ao caráter lúdico de ações encontradas nos rituais. Essas ações se caracterizam como algo que não é real em todas as suas instâncias. Nesse sentido, o jogo diz respeito a uma ação ambígua, que mexe com a realidade e não se caracteriza com algo inteiramente sério. É, principalmente, no jogo que surgem comportamentos novos.

Os rituais podem ser diferenciados por serem mais ou menos permeados pelo jogo. As rinhas são profundamente permeadas pelo jogo. Atitudes ambíguas marcadas por uma não seriedade estão presentes a todo o momento nas rinhas. O jogo está tão permeado nessa prática, que se pode dizer que a rinha de galos é em si um jogo. Do ponto de vista formal, o jogo se assemelha muito a uma performance ritual, porém o jogo diz respeito mais especificamente ao lado lúdico, ambíguo e jocoso presente nas práticas humanas, inclusive no ritual, onde pode ser mais facilmente realçado. Johan Huizinga (2000) resume as características formais do jogo desse modo: 
... poderíamos considerá-lo uma atividade livre, conscientemente tomada como "não-séria" e exterior à vida habitual, mas ao mesmo tempo capaz de absorver o jogador de maneira intensa e total. É uma atividade desligada de todo e qualquer interesse material, com a qual não se pode obter qualquer lucro, praticada dentro de limites espaciais e temporais próprios, segundo uma certa ordem e certas regras. Promove a formação de grupos sociais com tendência a rodearem-se de segredo e a sublinharem sua diferença em relação ao resto do mundo por meio de disfarces ou outros meios semelhantes. (Huizinga, 2000: 14).

As rinhas de galos que frequentei apresentam todos esses aspectos citados. Primeiro, é uma atividade livre, no sentido de que não há obrigação para participação dos indivíduos, ou seja, não há uma penalização caso alguém não participe ou queira deixar de comparecer a esses eventos. Segundo, é exterior a vida cotidiana, já que é um ritual realizado em espaços/tempo extraordinários: fins de semana, lugares longínquos, com um ritmo e dinâmica diferente da vida "normal" e regras próprias. Terceiro, envolve o segredo e promove a formação de grupos. Quarto, por fim, apesar de alguns poderem argumentar que essa atividade visa lucro, por ter apostas (dinheiro), posso afirmar, sem medo de errar, que o envolvimento com dinheiro nessa atividade, por parte dos galistas e jogadores não visa o lucro ${ }^{26}$. Existe uma ideia corrente entre os participantes das rinhas de que não se ganha dinheiro com briga de galos, se gasta mais com a criação dos mesmos do que se ganha com as apostas (quando se ganha). A aposta existe mesmo para promover a excitação, ou como disse um dos meus interlocutores: "para estimular a brincadeira da turma, pra fazer a resenha entre o pessoal. Ninguém fica rico com briga de galos não. Quando a gente ganha uma aposta gasta tudo com os galos ou bebendo com os amigos".

No tocante a predominância masculina, na briga de galos, podemos falar da existência de uma performance de gênero, de uma performance masculina. Essa performance, tem historicamente, uma relação com as práticas esportivas. No texto “Corporeidade, Esporte e Identidade Masculina" Gastaldo \& Braga (2011), a partir da noção de "técnica corporal" (Mauss, 2003), demonstra como certas técnicas corporais aplicadas em determinados esportes (no caso as artes maciais) informam o que é valorizado e legitimado para a identidade masculina. Ao articular noções como

\footnotetext{
${ }^{26}$ Pode-se dizer que, dependendo da rinha, se esta for grande e vender comidas e bebidas, o único que lucra com elas é o "dono da casa". Em rinhas pequenas, como muitas que frequentei, o dono da rinha é um galista ou amigo dos galistas que promove, com a ajuda dos outros, apenas para que haja a "brincadeira". Quem organiza não perde nada, não tem gastos, mas em muitos casos não ganha com isso financeiramente. Todos donos de rinha que conheci trabalham em outras atividades, que é sua fonte de sustento principal. Como a rinha é perseguida não há como viver dela. Investir exclusivamente num rinhadeiro é um risco.
} 
"competitividade", “esporte" e "identidade masculina", este autor demonstra como o "campo esportivo" pode expressar valores sociais de determinados grupos.

Vale ressaltar aqui, que no nosso caso, o atleta é o galo, não o homem. Mesmo assim, ouso afirmar que as "técnicas corporais" aplicadas ao corpo desses animais não humanos por seus treinadores humanos - os métodos e técnicas de treinamentos já descritos - informam o que é valorizado pelos participantes desse universo como ethos, práticas e símbolos de masculinidade.

A briga de galos envolve treinamentos que trazem agilidade, firmeza (dureza) e força para os galináceos. Todos esses aspectos são profundamente valorizados não só no corpo desses animais, mas também no corpo dos humanos participantes. Vale salientar que tais aspectos não são bem quistos apenas na dimensão corporal dos indivíduos humanos, mas também no que eles chamam de "caráter". Ser homem na região é ter firmeza de caráter, força e coragem para enfrentar os riscos que as rinhas (e a vida) trazem. Todos esses aspectos, além de valorizados nos galináceos, são também práticas e símbolos bem quistos nos humanos do sexo masculino, justamente por estarem associados à virilidade. Quem não apresenta essas qualidades, para eles, está ligado ao que eles compreendem como "feminino", ao não masculino.

Além disso, o universo da briga de galos envolve temas e, portanto, posturas de combate, de disputa e enfrentamento.

\footnotetext{
A prática de disputas e competições pode ser considerada uma característica bastante generalizada do ethos masculino, sendo um tema recorrente de pesquisas na área de ciências humanas. Em culturas as mais diversas, a afirmação social do 'ser homem' passa pela disputa com outros homens, seja do modo mais direto, em uma luta corpo a corpo, seja por vias mais sutis, como desafios verbais, torneios de insultos ou apostas em rinha de galos. (Gastaldo \& Braga, 2011: 880).

$\mathrm{Na}$ sociedade ocidental, em grupos bem mais próximos de nosso convívio, a competitividade é também é exacerbada e por vezes por vezes exigida socialmente, a aceitação de desafios sendo frequentemente uma das medidas da masculinidade. (Gastaldo \& Braga, 2011: 882).
}

Nesse sentido, a briga de galos pode ser entendida como uma ritualização que envolve performances de desafios, que visa afirmar a virilidade dos presentes, mediada pelo enfrentamento de animais não humanos. Quanto mais se aceita um desafio, mais se coloca a masculinidade em jogo nas rinhas, seja para ser insultada ou exaltada para uma plateia, também ávida por desafios. Correr esse risco de ter a masculinidade em jogo é justamente a principal forma de afirmá-la. 


\section{Considerações Finais}

A briga de galos, de maneira geral, é uma atividade bastante polêmica. Em muitos países, inclusive no Brasil, ela é considerada uma prática ilegal, principalmente, por colocar animais em combate, mas também por envolver apostas. Devido ao primeiro motivo, ela é tida por muitos como uma atividade "desumana", que envolve "maus tratos" e que é praticada por pessoas de má índole.

Confesso que eu, particularmente, partilhava de muitas dessas ideias, antes de adentrar esse universo. Porém, a antiguidade da briga de galos, a generalização da mesma e a comparação da vida dos galináceos que vivem para as rinhas com outros animais utilizados na indústria (alimentícia, de cosmético, de produção de couro, etc.), passei a relativizar e a me questionar o seguinte: Por que não existe uma ideia generalizada de que quem promove, trabalha, fomenta essas indústrias através da produção e do consumo de seus produtos que tem má índole? Por que não existe a ideia de que eles são indivíduos "desumanos" e que devam ser criminalizados como acontece com os galistas no contexto brasileiro?

Essa é uma questão que demanda mais pesquisas e leituras para ser respondida a contento. Não quero com esse questionamento diminuir a violência existente nas brigas de galos, mas apenas situar essa prática no mundo, comparando-a a outras atividades que também que envolvem "crueldade" com animais não humanos e que não são estigmatizadas (que não são poucas!). Faço isso para realizarmos um exercício de relativização, tão caro a antropologia.

Obviamente, não é necessário que os interessados no assunto visitem indústrias e abatedouros para ter o conhecimento mínimo de como é a vida dos animais utilizados pelas indústrias citadas, para que comparem com os métodos e técnicas de criação e treinamento dos galos combatentes descritos nesse artigo. Existem inúmeros filmes e vídeos que circulam na internet que demostram as condições de vida degradantes desses animais, dentre os mais conhecidos estão "Terráqueos" e "A Carne é Fraca". Porém, existe um curta específico, não tão conhecido, que eu gostaria de citar, não tanto pela sua qualidade, mas por se reportar a uma realidade próxima ao contexto dessa pesquisa: "Avate: a avicultura escancarada". Esse curta metragem documental, com forte apelo emocional e em tom de denuncia, reúne imagens de granjas do estado de Pernambuco, feitas entre dezembro de 2008 e fevereiro de 2009. 
A partir desses e de outros tantos vídeos de ativistas, podemos fazer aqui uma descrição rasa sobre a vida dos animais utilizados na indústria, para que comparemos, rapidamente, com os dados etnográficos dessa pesquisa. De maneira geral, os galináceos da avicultura são criados aos montes. As luzes do espaço onde vivem, não se apagam em nenhum momento. Eles são alimentados de forma exagerada para que possam produzir o máximo de carne no menor espaço de tempo possível. Isso faz com que esses animais vivam boa parte de suas vidas sem se sustentar em seus próprios corpos, o que os impossibilita de correr e ciscar, muitos não conseguem, nem mesmo, andar - o que faz com que eles desenvolvam enormes feridas em suas barrigas, que estão em contato constante com o solo. A maioria dessas granjas produzem animais prontos para o abate com apenas 42 dias, outras com 30 e já existem umas que reduziram para 21 dias de vida.

Diante de tamanha violência, por que não existe uma ideia generalizada de que quem trabalha na avicultura (para citar apenas essa indústria) seja um criminoso? Nem tão pouco existe um estigma que recai sobre os grandes fomentadores dessa indústria, nós os consumidores? Por que, então, o galismo sofre tamanho estigma? Devemos continuar criminalizando essa cultura? Será que usar animais para o lazer é realmente mais cruel do que usá-los para obter lucro, através da exploração, inclusive, de humanos? Por hora essas questões ficarão sem respostas. Pretendo, apenas, que tenha ficado claro, ao longo dessa pesquisa, que a prática do galismo não é algo "desumano", mas sim uma atividade humana, demasiadamente humana - para parafrasear Nietzsche. Digo isso porque a briga de galos certamente não é a atividade mais cruel que imprimimos aos animais não humanos. Existem inúmeras outras atividades promovidas e até valorizadas por nossas sociedades (como o uso de couro animal, por exemplo).

Com esse trabalho, quero que tenha ficado claro que essa é uma prática bastante diversa, e, que apesar de bastante generalizada, ainda é bastante desconhecida entre nós. Fato é que ela representa nossos impulsos coletivos e individuais de violentar, domesticar e exercer poder sobre outras espécies e sobre nós mesmo. Pode-se dizer que a briga de galos é um modo de demostrar força, de subjugar os mais fracos, de se divertir com a dor e o sofrimento alheio (seja ele um animal humano ou não humano), mas que nada disso é exclusivo dessa prática. 
Pude, ao longo desse artigo, descrever e interpretar as atividades das brigas de galos a partir de certas concepções da "antropologia da performance" e da consideração dos conceitos nativos, principalmente do trinômio (esporte, atleta e treinador). Nesse sentido, apresentei as atividades de bastidores (locais, métodos e técnicas de criação e treinamento dos animais); os diversos settings (rinhas) dessa atividade, como eles são organizados; como é pesada a participação animal e como é concebida a relação desses com os humanos; como se dá a interação social entre índios e não índios nesses espaços, quais as relações entre essa atividade e o contexto interétnico local; e, por fim, algumas situações específicas, ações e dramatizações que representassem as performances desse universo.

Mesmo que do ponto de vista legal, essa atividade não possa ser considerada um esporte no Brasil, ficou claro que a briga de galos é um universo "esportivizado", que traz consigo práticas, símbolos e signos do universo desportivo. Os métodos de criação e treinamento são verdadeiros corpus de conhecimento compartilhados entre redes de amigos, que também organizam os espaços de combate e mais parecem equipes esportivas que cooperam e competem entre si. Os galos são vistos e tratados como atletas - com uma rotina rigorosamente pensada - com alimentação e fármacos apropriados, por exemplo - e os humanos se pensam como treinadores. Essa ligação entre humanos e não humanos (treinadores e atletas) é tão estreita que não há como concebermos as performances de ambos sem relacioná-las: não existem galos de briga sem a intervenção humana, e a atuação desses animais influencia o cotidiano dos homens, muda o humor e até direciona o teor da conversa dos mesmos.

Ficou claro que as rinhas são eventos "liminóides" que ocorrem às margens da estrutura social local, com espaços e tempo limitados e regras próprias. Por esse motivo, esses ritos podem ser considerados como um momento de suspensão da estrutura social, mas podemos ver que nas rinhas essa suspensão não é total, como afirma Victor Turner. Em certas situações desse rito "liminóide" a estrutura social esteve presente e informou muitas coisas aos seus participantes (aqui me incluo), mesmo que de maneira sutil. Desse modo, ficou claro que as rinhas, de maneira geral, não operam com a mesma lógica do universo cotidiano, mas estão bastante ligadas a ele. Além da estrutura social aparecer em certos momentos, pudemos perceber que as rinhas põem em jogo temas, símbolos e signos do universo sociocultural local. 
Primeiro, a partir das rinhas podemos perceber que a identidade indígena (a etnicidade) é uma questão situacional, ou seja, que só se coloca em momentos específicos e que também está ligada a questões de classe. Segundo, no universo da briga de galos encontramos temas importantes do ponto de vista etnológico, como: parentesco, raça, sangue, mistura. Terceiro, as rinhas podem ser associadas metaforicamente ao contexto sociocultural da região, já que trazem consigo o contato interétnico, a disputa e a cooperação entre indígenas e não indígenas, tematiza a questão da disputa territorial (já que os galos brigam para expulsar o outro) e, por fim, elas trazem a temática da violência e do lazer, ambos aspectos bastante presentes no contexto local.

Observar as interações nas rinhas foi bastante profícuo para pensar o que é ser Potiguara. Ficou claro que não há como pensar isso sem levar em consideração as interações e relações estabelecidas entre indígenas e não indígenas da região. Ser Potiguara é ser "índio misturado", é ser Caboclo. Tal mistura não os deslegitima enquanto índios, muito pelo contrário, nesse contexto, ser Caboclo é ter inscrito no corpo, no modo de andar, de falar e de agir o parentesco com os antepassados indígenas. A denominação Caboclo (seja Velho, Legítimo, Civilizado, Brabo e/ou Cismado) é um demarcador de fronteira étnica da região que atesta a identidade indígena. Portanto, ser Caboclo é ser Índio.

Por fim, podemos perceber que todos os temas citados acima são vividos nas rinhas de maneira difusa, inversa e, por vezes, lúdica. Isso porque as rinhas são profundamente permeadas pelo jogo, por atitudes ambíguas, não sérias, e que têm como pano de fundo o desafio - uma dinâmica de interação historicamente associada ao universo masculino. Nesse sentido, as ações observadas nas rinhas são compreendidas como performances de gênero. Como ações que buscam demonstrar, afirmar ou insultar a virilidade dos participantes. Os galos são um meio para isso, um meio que permite os humanos dramatizarem (seja enquanto espectador ou treinador) sua masculinidade, sua força, sagacidade, coragem e medo. 


\section{Referências}

BARTH, Fredrik. Os grupos étnicos e suas fronteiras. In: BARTH, Frederik. O guru, o iniciador e outras variações antropológicas. Rio de Janeiro: Contra Capa, 2000, pp. 25-67.

CANCLINI, Néstor García. Culturas Híbridas. São Paulo: Editora da Universidade de São Paulo, 2006.

CARDOSO DE OLIVEIRA, Roberto Cardoso de. Antropologia e a crise dos modelos explicativos. Estudos Avançados, São Paulo, v. 9, n. 25, p. 213-228, dez. 1995.

CORREAA, Misael Costa. Alectoromaquia: Os galos de briga dentro da história ambiental. Fronteiras: Revista Catarinense de História, Florianópolis, v. 23, p. 198-215, 2014.

GASTALDO, Edison Luiz \& BRAGA, Adriana Andrade. Corporeidade, Esporte e Identidade Masculina. Revista de Estudos Feministas, vol. 19, núm. 3, set-dez, p. 875-893, 2011.

GEERTZ, Clifford. Um Jogo Absorvente: notas sobre a briga de galos Balinesa. In: GEERTZ, Clifford. A Interpretação das Culturas: ensaios selecionados. Rio de Janeiro: Zahar Editores, 1978 [1973].

GOFFMAN, Erving. A Representação do Eu na Vida Cotidiana. 12. ed. Petrópolis: Vozes. 1985 [1959].

GRÜNEWALD, Rodrigo de Azeredo (Org.). Toré: regime encantado do índio do Nordeste. Recife: Fundaj, Editora Massangana, 2005.

HUIZINGA, Johan. Homo Ludens. São Paulo, Editora Perspectiva S/A, 2000 [1938].

INGOLD, Tim. Nomear como Contar Histórias: falando de animais entre os Koyukon do Alaska. In: Estar Vivo: ensaios sobre movimento, conhecimento e descrição. Petrópolis, RJ: Vozes, 2015.

MALINOWSKI, Bronislaw. Objeto, Método e Alcance desta Pesquisa. In: GUIMARÃES, A. Z. (org.). Desvendando Máscaras Sociais. Rio de Janeiro, Francisco Alves, 1980. p. 39-61.

LANGDON, Esther Jean. Rito como conceito-chave para a compreensão de processos sociais. In: LANGDON, Esther. Jean. \& PEREIRA, Éverton. Luís. (Org.). Rituais e Performances: iniciações em pesquisa de campo. Florianópolis: UFSC/Departamento de Antropologia. 2012.

MATOS, Rafael. Leal. Bebendo no Cajueiro: um ensaio etnográfico sobre o consumo de bebidas alcoólicas na aldeia Potiguara do Forte. Monografia (Graduação em Ciências Sociais), Unidade Acadêmica de Ciências Sociais, Universidade Federal de Campina Grande, 2013.

MAUSS, Marcel. As técnicas do corpo. In:___ Sociologia e Antropologia. São Paulo: Cosac Naify, 2003, p.399-422.

MAUSS, Marcel. A Prece. In: MAUSS, M. Ensaios de Sociologia. São Paulo: Perspectiva. 1981 [1909].

NEVES, Rita de Cássia Maria. Dramas e Performances: o processo de reelaboração étnica Xukuru nos rituais, festas e conflitos. Tese (Mestrado em Antropologia Social), Universidade Federal de Santa Catarina, Florianópolis, 2011.

OLIVEIRA, João Pacheco. Uma etnologia dos índios misturados? Situação colonial, territorialização e fluxos culturais. Mana - Estudos de Antropologia Social, Rio de Janeiro, PPGAS/Museu Nacional/UFRJ, 1998.

PALITOT, Estêvão Martins. Os Potiguara da Baía da Traição e Monte-Mor: história, etnicidade e cultura. Dissertação (Mestrado em Sociologia), Universidade Federal da Paraíba, João Pessoa, 2005b.

Todos os Pássaros do Céu: o Toré Potiguara. In: GRÜNEWALD, Rodrigo (Org.). Toré: regime encantado do índio do Nordeste. Recife: Fundaj, Editora Massangana, 2005a. p. 187-219.

RINHA. In: Dicionário Michaelis. Disponível em: <http://michaelis.uol.com.br/>. Acesso em: 08 de maio de 2015.

SCHECHNER, Richard. Jogo. In: LIGIÉRO, Zeca. (Org.). Performance e Antropologia de Richard Schechner. Rio de Janeiro: Mauad, 2012. 
SILVA, Renato Carvalho Santos. De Homens e Galos: um estudo antropológico sobre "um jogo absorvente" na região central do Rio Grande do Sul. Dissertação (Mestrado em Ciências Sociais), Universidade Federal de Santa Maria, Santa Maria, 2011.

TURNER, Victor. Liminaridade e Communitas. In: TURNER, Victor. O Processo Ritual: Estrutura e Antiestrutura. Petrópolis. Vozes. 1974. p. 116-157.

. Liminal ao Liminóide: em brincadeiras, fluxo e ritual. Um Ensaio de Simbologia Comparativa. Londrina, Mediações, v. 17 n. 2, p. 214-257, Jul./Dez. 2012

VAN GENNEP, Arnold. Os Ritos de Passagem. Petrópolis. Ed. Vozes, 1978 [1909].

VIEIRA, José Glebson. Amigos e Competidores: política faccional e feitiçaria nos Potiguara da Paraíba. São Paulo, Humanitas, 2012.

Recebido em: 20/10/2016.

Aprovado em: 06/12/2016. 